УДК: 37.042 .1

\title{
ПРОБЛЕМА РОЗВИТКУ ШВИДКІСНО-КООРДИНАЦІЙНИХ ЗДІБНОСТЕЙ СТАРШИХ ШКОЛЯРІВ
}

\author{
Вадим Щирба ${ }^{1}$ \\ ${ }^{1}$ Ліцей-інтернат №23 «Кадетський корпус» із посиленою військово-фізичною підготовкою, Київ, \\ mara99@meta.ua \\ https://doi.org/10.29038/2220-7481-2019-04-82-87
}

\begin{abstract}
Анотації
Bcmyn. Нинішній ландшафт фізичної культури на теренах нашої держави, на жаль, перебуває в дуже важкому стані. Сумні реалії проведення уроків фізичної культури, секційних занять, рухливих перерв, фізкультурних хвилинок та пауз доводять, що сучасному «поколінню $Z$ » зовсім не цікаві «ретроспективні» та «запозичені» методи виховання в сучасній школі. Мета дослідження - проаналізувати стан проблеми розвитку швидкісно-координаційних здібностей школярів 10-11 класів. Методи дослідження - теоретичний аналіз та синтез, аналіз науково-методичної літератури, методи математичної статистики. Учасники дослідження. Це дослідження проводили на базі ліцею-інтернату № 23 із посиленою військово-спортивною підготовкою Шевченківського району міста Києва. Під час проведення дослідження задіяно 106 школярів 10-11 класів (n=106). Дітей та їхніх батьків інформовано про всі особливості дослідження; вони дали згоду на участь в експерименті. Результати дослідження. У процесі аналізу отриманих показників швидкісно-координаційних здібностей за допомогою тесту «Подвійна стріла» виявлено такі результати: середній показник становить

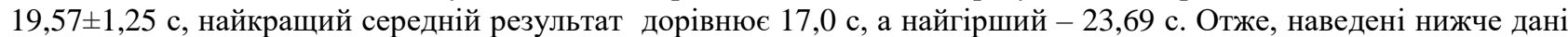
свідчать про те, що в досліджуваних школярів 10-11 класів спостерігаємо стабільність результатів у межах 1821 секунди. Висновки. Запропоновано тест для оцінки розвитку швидкісно-координаційних здібностей дітей. Аналіз дослідження дав підставу з'ясувати, що розвиток швидкісно-координаційних здібностей є однією 3 невід'ємних складових частин процесу підготовки школярів і юних спортсменів, але водночас залишається досі одним із найменш розроблених розділів підготовки в спорті. Упровадження в практику тесту «Подвійна стріла» для швидкісно-координаційної підготовки юних спортсменів і школярів сприятиме більш якісному засвоєнню й удосконаленню цих фізичних якостей.
\end{abstract}

Ключові слова: фізична підготовка, здібності, школярі, тест «подвійна стріла».

Вадим Щирба. Проблема развития скоростно-координационых способностей старших школьников. Bступление. Современный ландшафт физической культуры в нашем государстве, к сожалению, находится в очень трудном состоянии. Печальные реалии проведения уроков физической культуры, секционных занятий, подвижных перерывов, физкультурных минуток и пауз доказывают, что современному «поколению Z» совсем не интересны «ретроспективные» и «заимствованные» методы воспитания в современной школе. Цель исследования - проанализировать состояние проблемы развития скоростно-координационных способностей школьников 10-11 классов. Методы исследования - теоретический анализ и синтез, анализ научно-методической литературы, методы математической статистики. Участники исследования. Данное исследование проводилось на базе лицея-интерната № 23 с усиленной военно-спортивной подготовкой Шевченковского района города Киева. При проведении исследования задействованы 106 школьников 10-11 классов (n = 106). Дети и их родители были осведомлены обо всех особенностях исследования и дали согласие на участие в эксперименте. Результаты исследования. При анализе полученных показателей скоростно-координационных способностей при помощи теста «Двойная стрела» наблюдались следующие результаты: средний результат

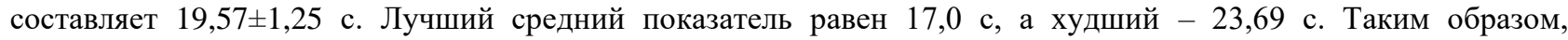
приведенные ниже данные свидетельствуют о том, что в исследуемых школьников 10-11 классов наблюдается стабильность результатов в пределах 18-21 секунды. Выводы. Предлагается тест для оценки развития скоростно-координационных способностей детей. Анализ исследования позволил выяснить, что развитие скоростно-координационных способностей является одной с неотрицательных составляющих процесса подготовки школьников и юных спортсменов, но, вместе с тем, остается до сих пор одним из наименее разработанных разделов подготовки в спорте. Внедрение в практику теста «Двойная стрела» для скоростнокоординационной подготовки юных спортсменов и школьников будет способствовать более качественному усвоению и совершенствованию данных физических качеств.

Ключевые слова: физическая подготовка, способности, школьники, тест «двойная стрела».

Vadym Shchyrba. Problem of Development of Speed-Coordination Abilities of Senior Schoolchildren. Unfortunately, in nowadays the view of physical culture in our state is very fragile. Sad realities of physical education 
lessons, sport clubs, moving breaks, physical activities and pauses prove that our «generation $Z$ » is completely uninterested in «retrospective» and «borrowed» methods of training in modern school. The Purpose of the Research is to analyze the problem of development of speed-coordination abilities of 10-11 grade schoolchildren. Research Methods. Theoretical analysis and synthesis, analysis of scientific and methodological literature, methods of mathematical statistics. Researchers. This research was conducted on the basis of the Lyceum-boarding school No 23 «Cadet Corps» with intensive military-sports training of the Shevchenko district of Kyiv. During researching 106 schoolchildren of $10-11$ grade were involved $(n=106)$. Children and their parents were informed of all the peculiarities of the study and agreed to participate in the experiment. Research Results. In the analysis of the obtained indicators of speed-coordination abilities due to the «Double Arrow» test, the following results were found: the average result is $19,57 \pm 1,25 \mathrm{sec}$. The best average result is $17,0 \mathrm{sec}$, and the worst average is $23.69 \mathrm{sec}$. Thus, the following data indicate that the schoolchildren of 10-11 grade demonstrate a stability of the results within 18-21 seconds. Conclusions. It was proposed the test for assessing the development of speed-coordination abilities of children. An analysis of the research paper made it possible to find out that the development of speed-coordination abilities was one of the inalienable components of the training process for schoolchildren and young athletes. But at the same time it remains to stay one of the least developed sections of training in sports. The introduction of the «Double Arrow» test for speed-coordination training of young athletes and students will contribute to better assimilation and improvement of physical fitness data.

Key words: physical preparedness, abilities, senior schoolchildren, «Double Arrow» test.

Вступ. Сучасний ландшафт фізичної культури на теренах нашої держави, на жаль, перебуває в дуже крихкому стані. Сумні реалії проведення уроків фізичної культури, секційних занять, рухливих перерв, фізкультурних хвилинок та пауз доводять, що сучасному «поколінню Z» зовсім не цікаві «ретроспективні» й «запозичені» методи виховання в сучасній школі.

Одне $з$ провідних місць у життєдіяльності людини посідають координаційні здібності, які визначають саму можливість і результативність рухової діяльності, займають важливе місце в управлінні багатьма рухами, мають важливе значення для підготовки людини до трудової та оборонної діяльності; чим вищий рівень їхнього розвитку, тим швидше й краще людина засвоює й використовує рухові дії в кожній конкретній ситуації [4; 5].

Високий рівень розвитку координаційних здібностей (К3), досягнутий на початкових етапах спортивного тренування, є важливим фактором оптимізації координаційної й технічної підготовки, який дає змогу запобігти застою в рості результатів, робить змагальні рухи економними, варіативними, різноманітними та, урешті, більш ефективними. Крім того, широка координаційна підготовка на початкових етапах тренування дає змогу легше засвоювати нові форми рухів і тим самим збагачувати руховий досвід юних спортсменів [6].

У системі управління рухами одним 3 основних понять, на основі якого будуються інші, $є$ координація рухів - «організація керування руховим апаратом» [2].

Рівень розвитку координаційних здібностей визначали за показниками виконання тестів, представлених у державній програмі з фізичної культури для загальноосвітніх навчальних закладів «Фізична культура. 5-11 класи», а також застосовували додаткові тести, запропоновані Л. П. Сергієнко, В. А. Романенко.

На сьогодні існує така ситуація, що вчителі фізичної культури приділяють дуже мало уваги саме швидкісно-координаційним здібностям школярів.

Провівши детальний аналіз науково-методичної літератури, ми виявили, що питанню розвитку координаційних і швидкісних здібностей у школярів старшого шкільного віку приділяють дуже мало уваги. Отже, дослідження рівня розвитку швидкісно-координаційних здібностей старших школярів $є$ актуальним і потребує подальшого вивчення.

Аналіз й узагальнення літературних джерел із проблем контролю рівня фізичної підготовленості старших школярів дає можливість стверджувати про необхідність комплексного вивчення контролю фізичної підготовленості школярів, а також розробку та введення в програму з фізичної культури нових тестів для оцінки фізичних якостей.

Мета дослідження - проаналізувати стан проблеми розвитку швидкісно-координаційних здібностей школярів 10-11 класів.

Матеріали та методи дослідження. Це дослідження проводили на базі ліцею-інтернату № 233 посиленою військово-спортивною підготовкою Шевченківського району міста Києва. Під час реалізації дослідження задіяно 106 школярів 1-11 класів $(n=106)$. Дітей та їхніх батьків інформовано про всі особливості дослідження; вони дали згоду на участь в експерименті. 
Методи дослідження - теоретичний аналіз та синтез, аналіз науково-методичної літератури. Обробку статистичних даних проводили за допомогою методів математичної статистики. Вірогідність різниці між середніми величинами визначали за t-критерієм Стьюдента 3 попередньою перевіркою гіпотези про нормальний розподіл результатів вимірювання за допомогою критерію Шапіро-Уілкі.

Систему оцінювання швидкісно-координаційних здібностей старших школярів розробили, застосовуючи сигмальний метод статистичного аналізу.

Організація дослідження. Для контролю за розвитком координаційних здібностей запропоновано тест «Подвійна стріла».

Обладнання - шість конусів висотою 40 сантиметрів, рулетка, секундомір.

Статистичний аналіз. Результати цього дослідження піддано математично-статистичній обробці. Математично-статистичну обробку отриманих результатів дослідження виконували 3 використанням пакета прикладних програм MS Excel.

Результати дослідження. За командою «На старт!» учасник займає положення високого старту за стартовою лінією в точці А (рис.1). За командою «Руш!» він пробігає дистанцію цього тесту за такою послідовністю:

- крок № 1 - відрізок дистанції від точки А до наступної точки В спортсмен виконує прискорення в максимальному темпі;

- крок № 2 - відрізок дистанції від точки В до наступної точки С спортсмен виконує біг приставним кроком, правим боком;

- крок № 3 - відрізок дистанції від точки С до наступної точки А спортсмен виконує біг спиною назад;

- крок № 4 - відрізок дистанції від точки А до наступної точки А1 спортсмен виконує ривок у максимальному темпі;

- крок №5 - відрізок дистанції від точки А1 до наступної точки С1 спортсмен виконує біг спиною назад;

- крок № 6 - відрізок дистанції від точки С1 до наступної токи В1 спортсмен виконує біг приставним кроком, лівим боком;

- крок № 7 - відрізок дистанції від точки В1 до наступної точки А1 спортсмен виконує прискорення в максимальному темпі;

- крок № 8 - відрізок дистанції від точки А1 до наступної точки А спортсмен виконує ривок у максимальному темпі.

Результатом тестування є час від старту в точці А до моменту, коли учасник тестування подолав усю дистанцію й завершив її в тій самій точці А. Учасник виконує дві спроби з інтервалом-відпочинком між ними 2 хв. Результатом учасника потрібно рахувати середній результат спортсмена під час цього тестування, тобто суму двох спроб, розділену навпіл. Довжина тесту «Подвійна стріла» становить 60 м. Учасник цього тесту повинен якнайшвидше пройти дистанцію, координуючи свої рухи, чітко й точно оминати всі етапи проходження, не торкаючись фішок (рис.1).

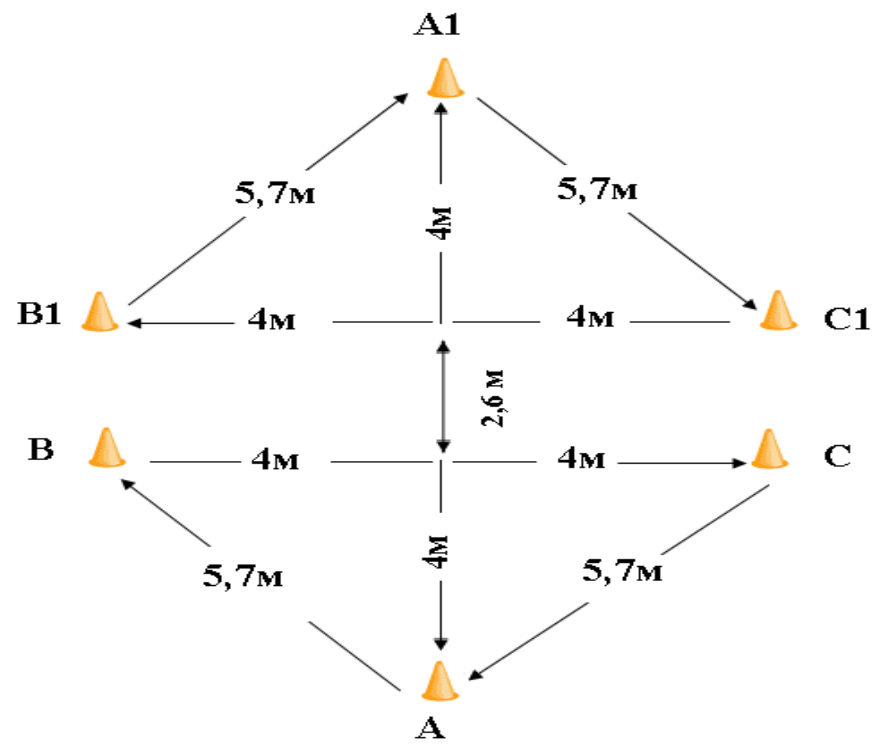

Рис 1. Схема виконання тесту «Подвійна стріла» 
Під час аналізу отриманих показників швидкісно-координаційних здібностей за допомогою тесту «Подвійна стріла» виявлено такі результати: середній показник становить $19,57 \pm 1,25$ с, найкращий середній результат - 17,0 c, а найгірший - 23,69 с (рис. 2). Отже, наведені нижче дані свідчать про те, що в досліджуваних школярів 10-11 класів спостерігали стабільність результатів у межах 18-21 секунди.

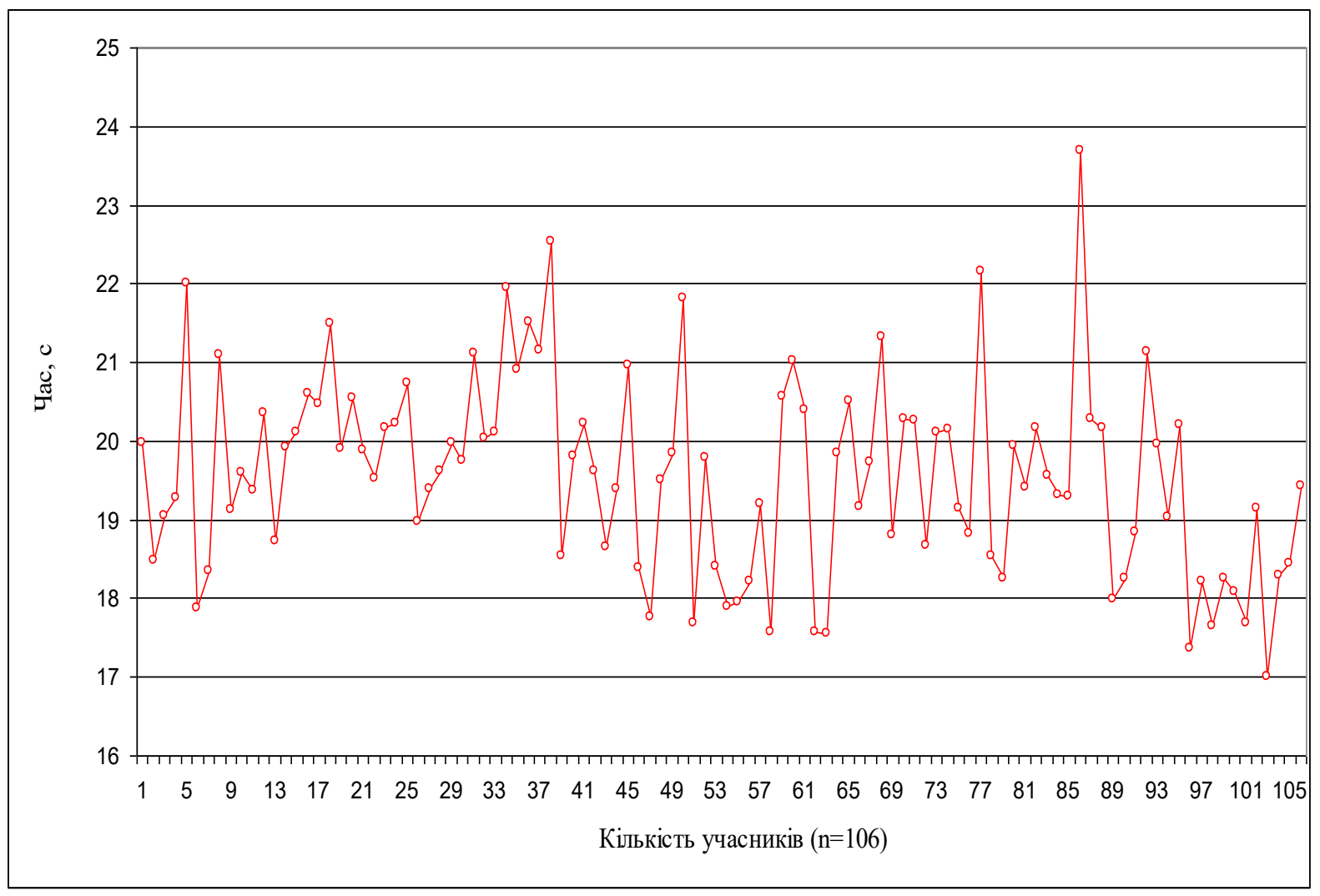

Рис 2. Показники розвитку швидкісно-координачійних здібностей старшокласників за допомогою тесту «Подвійна стріла»

$\longrightarrow$ - середній результат стариокласники.

Розглядаючи показники цього тесту, можемо зробити висновок, що більша кількість учасників покращують свої результати в другій спробі (рис. 3) та якщо порівнювати середні значення першої та другої спроб, то ми бачимо тенденцію до зниження середнього результату в першій спробі. Середній результат першої спроби становить $19,74 \pm 1,22$ с, а другої - 19,41 $\pm 1,35$. Найкращий показник першої спроби становить 17,0 с, а другої - відповідно 17,01 c, покращення - на 0,01 секунди, тоді як найгірший результат першої спроби - 24,31 с, а другої - 23,07 с, покращення - на 1,24 секунди.

69 учасників тесту «Подвійна стріла» покращили свої результати, в одного учасника тестування результат залишився однаковим у двох спробах. Як бачимо, 72 \% досліджуваних показали кращі результати другої спроби, тому аргументація середнього результату учасників тесту є цілком правильною.

Дискусія. Результати дослідження значно розширюють дані про розвиток швидкісно-координаційних здібностей як частини фізичної підготовки школярів та юних спортсменів. На жаль, у науковометодичній літературі цьому питанню приділяється дуже мало уваги.

Досліджені дані дають змогу стверджувати, що в нинішній ситуації у сфері фізичної культури цей тест вніс би «ковток свіжого повітря» в систему тестів, які стають неактуальними й поступово починають «виходити $з$ моди». Адже нове покоління дітей жадає чогось нового, також це має великий стосунок і до уроків фізичної культури, а не «стандартно-сірих» та нудних тестів які (будемо відверті) не зацікавлюють школярів.

Школярі потребують як зовнішніх, так і внутрішніх стимулів щодо занять фізичною культурою й спортом. Якщо поглянути на панораму рівня рухової активності учнів, під зовсім іншою призмою «незаангажованих псевдозвітів», то вона, на жаль, не відповідатиме дійсності. 


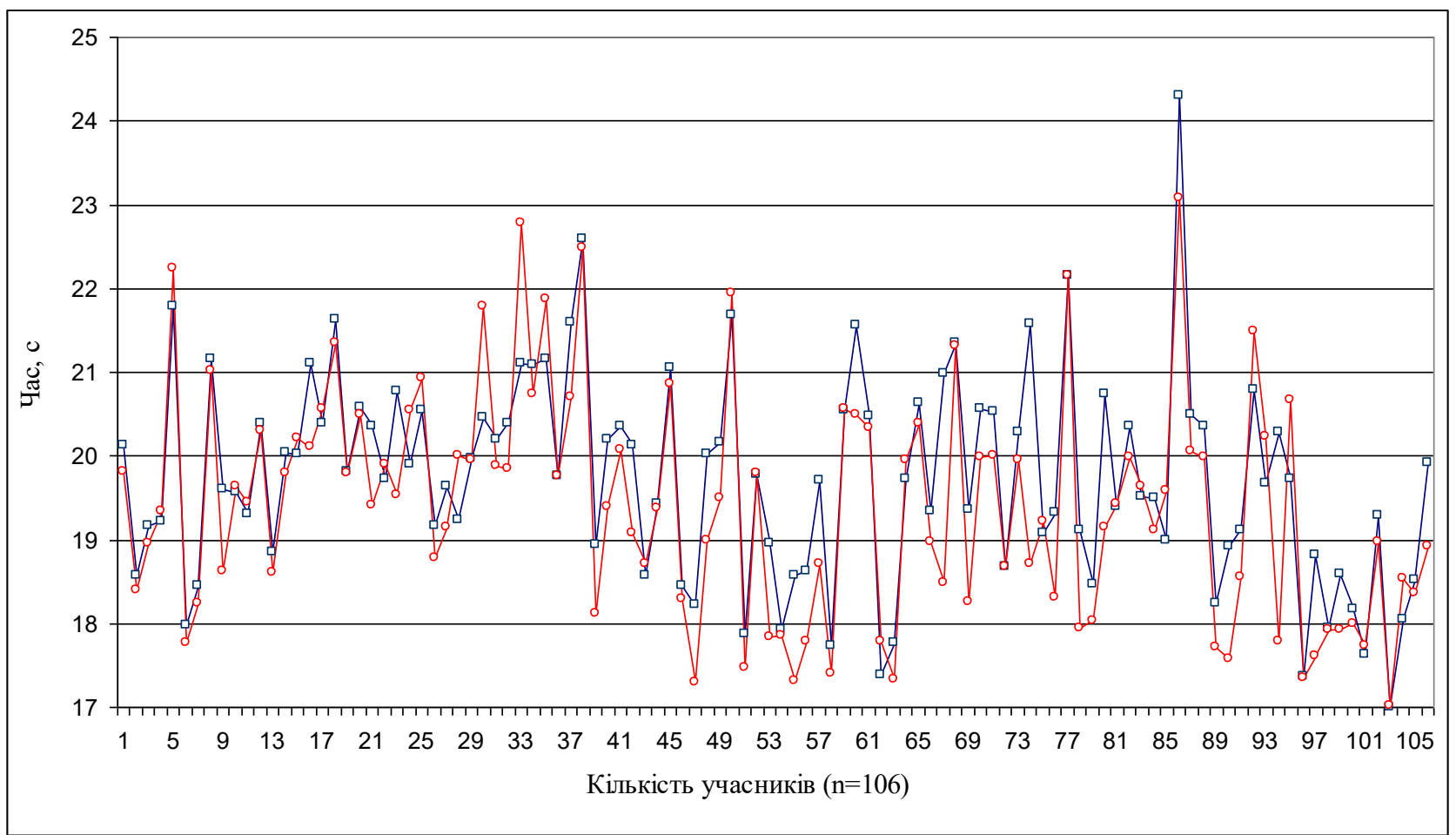

Рис 3. Динаміка зміни показників розвитку швидкісно-координаційних здібностей у першій та другій спробі стариих школярів за допомогою тесту «Подвійна стріла»

$$
\begin{aligned}
& \longrightarrow-1 \text { спроба старшокласника; } \\
& -2 \text { спроба стариокласника. }
\end{aligned}
$$

Упровадження НУШ у систему сучасної освіти вимагає розробки нових тестів та конструктивну реконструкцію, а також модернізацію тестування з фізичної культури, які повинні відповідати чинним закономірностям визначення рівня фізичної підготовленості учнів, що дають змогу корегувати динаміку змін рухових здібностей.

Доцільність розширення й упровадження в практику нових тестів зумовлена значними змінами способу рухової активності школярів, а також станом їхнього здоров'я. Розробка авторських тестів повинна підвищити ефективність оцінювання в системі фізичного виховання.

Висновки та перспективи подальших досліджень. Аналіз дослідження автора дав змогу з'ясувати, що розвиток швидкісно-координаційних здібностей є однією з невід'ємних складових частин процесу підготовки школярів та юних спортсменів, але водночас залишається досі одним із найменш розроблених розділів підготовки в спорті. Упровадження в практику тесту «Подвійна стріла» для швидкісно-координаційної підготовки юних спортсменів і школярів сприятиме більш якісному засвоєнню й удосконаленню цих фізичних якостей.

Проведене дослідження, на жаль, не є кінцевим рішенням проаналізованої проблеми. Мабуть, це підтвердження необхідності щодо подальших більш якісних теоретико-методичних напрацювань i вдосконалення практики впровадження інноваційних тестів у систему шкільної фізкультурної освіти.

Аналіз напрацьованого матеріалу дасть змогу розробити більш точну та якісну систему оцінювання швидкісно-координаційних здібностей.

Перспективи подальших досліджень полягають у розробці комплексної оцінки цього тесту, а також у моделюванні нормативів оцінки розвитку швидкісно-координаційних здібностей, розрахованих за 5- і 12 сигмальними шкалами для учнів 10-11 класів за допомогою тесту «Подвійна стріла».

\section{Джсерела та література}

1. Батуев А. С. Физиология высшей нервной деятельности и сенсорних систем: учеб. для вузов. 3-е изд. Санкт-Петербург: Питер, 2009, С. 61-98.

2. Бернштейн Н. А. О ловкости и ее развитии. Москва: Фізкультура и спорт. 1991. 228 с.

3. Верхошанский Ю. В. Основы специальной физической подготовки спортсмена. Москва: Физкультура и спорт, 1998. $331 \mathrm{c}$. 
4. Кузьменко І. О. Зміна рівня розвитку окремих координаційних здібостей школярів середніх класів під впливом спеціально спрямованих вправ. Молода спортивна наука України: зб. наук. праць з галузі фізичної культури та спорту. Вип. 14: у 4-х т. Львів, 2010. Т. 2. 124-130 с.

5. Кузьменко И. А. Возрастные особенности развития координационных способностей школьников средних классов. Физическая культура, спорт и туризм. Интеграционные процессы науки и практики: материалы V междунар. науч.-практ. конф., 19-23 апреля. 2012 г. Орел: Госуниверситет-УНПК, 2012. C. $25-30$.

6. Лях В. И., Садовски Е. О концепциях, задачах, месте и основных положениях координационной подготовки в спорте. Теория и практика физической культуры. 1998. № 2. С. 56-59.

7. Романенко В. А. Диагностика двигательных способностей: учеб. пособие. Донецк: Дон НУ, 2005. 290 с.

8. Сергієнко Л. П. Спортивна метрологія : теорія і практичні аспекти: підручник. Київ: КНТ, 2010. 776 с.

9. Сергиенко Л., Селезнева Т., Кисть Л., Нам С. Педагогический контроль развития координационных способностей у детей и подростков. Наука в олимпийском спорте. 2002. № 1. С. 47-53.

10. Шамардина Г. Н. Основы теории и методики физического воспитания. Днепропетровск: Пороги, 2003. $454 \mathrm{c}$.

11. Шестерова Л. Є. Вплив рівня активності сенсорних функцій на удосконалення рухових здібностей школярів середніх класів: автореф. дис. на здобуття наук. ступеня канд. наук з фіз. вих. і спорту: спец. 24.00 .02 «Фізична культура, фізичне виховання різних груп населення». Харків, 2004. 20 с.

\section{References}

1. Batuev, A. S. (2009). Fiziologiya vyisshey nervnoy deyatelnosti i sensornih sistem: Uchebnik dlya vuzov, 3-e uzd. PSb, Piter, 61-98.

2. Bernshteyn, N. A. (1991). O lovkosti i ee razvitii. Moskva: Fizkultura i sport, 228.

3. Verhoshanskiy, Yu. V. (1998). Osnovyi spetsialnoy fizicheskoy podgotovki sportsmena. Moskva: Fizkultura i sport, 331.

4. Kuzmenko, I. O. (2010). ZmIna rIvnya rozvitku okremih koordinatsIynih zdibostey shkolyariv serednIh klasiv pid vplivom spetsialno spryamovanih vprav. Moloda sportivna nauka Ukrayini : zb. nauk. prats $z$ galuzI fIzichnoyi kulturi ta sportu, Vip. 14: u 4-h t. Lviv, T. 2, 124-130.

5. Kuzmenko, I. A. (2012). Vozrastnyie osobennosti razvitiya koordinatsionnyih sposobnostey shkolnikov srednih klassov. Fizicheskaya kultura, sport i turizm. Integratsionnyie protsessyi nauki i praktiki: materialyi V mezhdunarodnoy nauchno-prakticheskoy konferentsii, 19-23 aprelya 2012 g. Orel: Gosuniversitet-UNPK, 25-30.

6. Lyah, V. I., Sadovski E. O. (1998). kontseptsiyah, zadachah, meste i osnovnyih polozheniyah koordinatsionnoy podgotovki v sporte. Teoriya i praktika fizicheskoy kulturyi, № 2, 56-59.

7. Romanenko, V. A. (2005). Diagnostika dvigatelnyih sposobnostey. Uchebnoe posobie. Donetsk: Don NU, 290.

8. Sergienko, L. P. (2010). Sportivna metrologiya : teoriya i praktichni aspekti : Pidruchnik. Kyiv: KNT, 776.

9. Sergienko, L., Selezneva T., Kist L., Nam S. (2002). Pedagogicheskiy kontrol razvitiya koordinatsionnyih sposobnostey u detey i podrostkov. Nauka v olimp. Sporte, № 1, 47-53.

10. Shamardina G. N. (2003). Osnovyi teorii i metodiki fizicheskogo vospitaniya. Dnipropetrovsk: Porogi, 454.

11. Shesterova, L. Ye. (2004). Vplyv rivnia aktyvnosti sensornykh funktsii na udoskonalennia rukhovykh zdibnostei shkoliariv serednikh klasiv: avtoref. dys. na zdobuttia nauk. stupenia kand. nauk z fiz. vykh. i sportu: spets. 24.00.02 «Fizychna kultura, fizychne vykhovannia riznykh hrup naselennia». Kharkiv, 20.

Стаття надійшла до редакції 18.11.2019 р. 